\title{
ACRL officers for 1988-89
}

\section{The official ACRL election results.}

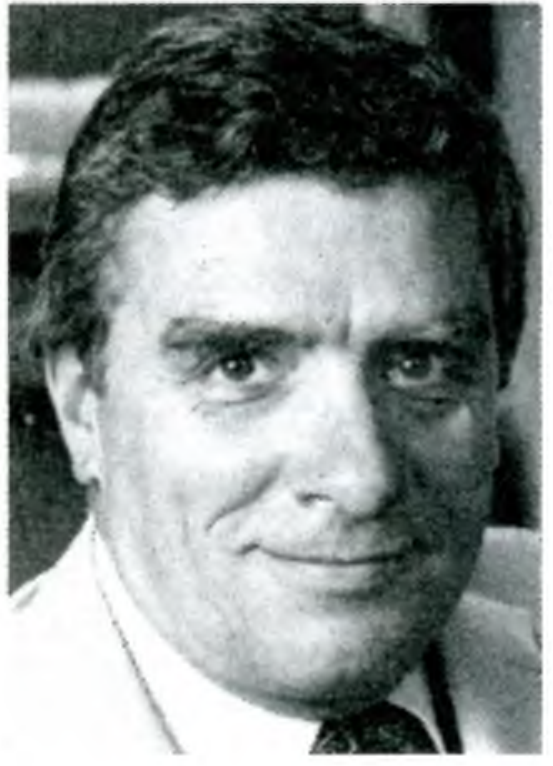

Joseph A. Boissé

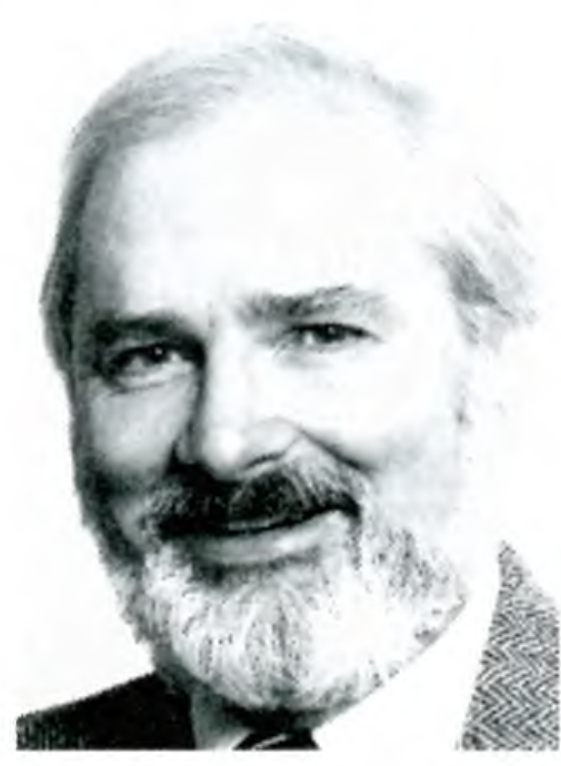

William A. Moffett
Joseph A. BoIsSÉ, university librarian at the University of California, Santa Barbara (Santa Barbara, CA 93106), is the fifty-first president of the Association of College and Research Libraries. During his one-year term of office, he will preside over the ACRL Board of Directors and the ACRL Executive Committee. He will chair the ACRL Conference Program Planning Committee for the 1989 Annual Conference in Dallas and will plan ACRL's major program at the conference.

As president of the division, Boissé will represent ACRL on the ALA Dallas Conference Program Planning Committee and the ALA Planning and Budget Assembly. He will also represent ACRL and ALA in their relations with other organizations. Boissé has been very active in ACRL and has served on the Legislation, Continuing Education, and Appointments and Nominations Committees. He was a member of the ACRL Task Force on Libraries in Higher Education in 1982-1984 and the LAMA Board of Directors in 1980-1982.

William A. Moffett, director of libraries at Oberlin College (Oberlin, OH 44074), has been elected vice-president/president-elect of the Association of College and Research Libraries. The
1988 election results showed 1,784 votes for Moffett and 1,009 for David B. Walch, Dean of Library and Audiovisual Services at Cal Poly, San Luis Obispo, CA 93407.

As vice-president/president-elect of ACRL, Moffett will serve on the ACRL Board of Directors and the ACRL Executive Committee. He will chair the ACRL Conference Program Planning Committee for the 1990 Annual Conference in Chicago. He will represent ACRL on the ALA Appointments Committee and the ALA Conference Program Planning Committee for the 1990 Conference. At the end of the 1989 Annual Conference he will become ACRL's fifty-second president.

Moffett served as chair of the ACRL College Libraries Section in 1984-85 and was instrumental in establishing the CLS National Advisory Council in 1986. He recently served as chair of the RBMS Security Committee, and has been a member of the Publications and Academic/Research Librarian of the Year Committees. Moffett was a featured speaker at the ACRL National Conference in Seattle in 1984 , where he presented his "Reflections of a College Librarian: Looking for Life and Redemption This Side of ARL."

The results of the ACRL elections follow. For each position, the elected candidate is listed first. The number of votes earned by each candidate is given in parentheses.

\section{Anthropology and Sociology Section}

Vice-Chair/Chair-Elect: JANET STEINS, Head, Chemistry Library, State University of New York, Stony Brook, NY 11794-3425 (58); G. Edward Evans, Librarian, Tozzer Library, Harvard University, Cambridge, MA 02138 (54).

Member-at-Large: MaIJA M. LuTz, Head of Technical Services, Tozzer Library, Harvard University, Cambridge, MA 02138 (55); David M. Hovde, Social Sciences Librarian, University of Oklahoma, Norman, OK 73072 (53). 


\section{Art Section}

Vice-Chair/Chair-Elect: Paula MurPhy, Head of Audiovisual Services, Columbia College Library, Chicago, IL 60602 (78); Alice N. Loranth, Head of Fine Arts and Special Collections, Cleveland Public Library, Cleveland, OH 44114 (73).

\section{Asian and African Section}

Vice-Chair/Chair-Elect: Dona S. Straley, Middle East Librarian, Ohio State University, Columbus, OH 43210 (59); R.N. Sharma, Assistant Director of Public Services, University of Wisconsin, Oshkosh, WI 54901 (48).

Secretary: William SHEH Wong, Assistant Director of General Services for the Asian Library, University of Illinois, Urbana, IL 61801 (57); Margaret K. Wang, Coordinator of Original Cataloging, University of Delaware, Newark, DE 19717 5267 (47).

Member-at-Large: Julian W. Witherell, Chief, African and Middle Eastern Division, Library of Congress, Washington, DC 20540 (67); Donald Clay Johnson, Librarian, Ames Library of South Asia, University of Minnesota, Minneapolis, MN 55455 (41).

\section{Bibliographic Instruction Section}

Vice-Chair/Chair-Elect: Cerise Oberman, Public Services Planning Officer, University of Minnesota, Minneapolis, MN 55455 (491); Mignon Adams, Director of Library Services, Philadelphia College of Pharmacy and Science, Philadelphia, PA 19104 (394).

Secretary: Karen Williams, Central Reference Librarian, University of Arizona, Tucson, AZ 85721 (494); Carolyn B. Fields, Reference Librarian, San Diego State University, San Diego, CA 92182-0511 (321).

Member-at-Large: Carol F. Ahmad, Assistant Director for Public Services, University of Miami, Coral Gables, FL 33124 (482); Melanie Dodson, Head, Social Science/Documents Center, New York University, New York, NY 10012 (354).

\section{College Libraries Section}

Vice-Chair/Chair-Elect: JACQUELYN M. MORRIS, Director, Occidental College Library, Los Angeles, CA 90041 (281); Caroline M. Coughlin, Director, Drew University Library, Madison, NJ 07940 (205).

Secretary: George C. Grant, Director of Libraries, Rollins College, Winter Park, FL 32789 (249); Michael D. Kathman, Director of Libraries, St. John's University, Collegeville, MN 56321 (235).

Member-at-Large: Kari D. ANDERson, Reference Librarian, Mary Washington College, Fredericksburg, VA 22401 (235); Elizabeth D. Hammond, Associate Director, Mercer University Library, Macon, GA 31207 (208).
Member-at-Large (two-year term): MARY LEE SwEAT, University Librarian, Loyola University, New Orleans, LA 70118 (242); Susan M. Campbell, Library Director, York College of Pennsylvania, York, PA 17403-3426 (222).

\section{Community and Junior College Libraries Section}

Vice-Chair/Chair-Elect: W. LEE HISLE, Director of Learning Resource Services, Austin Community College, Austin, TX 78768 (146); Darleen B. Abbott, Acquisitions/Serials Librarian, Pensacola Junior College, Pensacola, FL 32504 (75).

Secretary: Marilyn M. MCDonald, Dean of Learning Resources, Foothill College, Los Altos Hills, CA 94022 (147); Suzanne Hill, Director of Library Services, Catonsville Community College, Baltimore, MD 21228 (75).

\section{Education and Behavioral Sciences Section}

Vice-Chair/Chair-Elect: LAurene E. ZAPOROZHETZ, Chair of Information Services, Bowling Green State University, Bowling Green, $\mathrm{OH}$ 43403 (173); Emily Fabiano, Reference Librarian/Education Specialist, Rutgers University, New Brunswick, NJ 08903 (159).

\section{Law and Political Science Section}

Chair: Natalie Schatz, Director, Fletcher School of Law and Diplomacy Library, Tufts University, Medford, MA 02155 (147); write-in (1).

Vice-Chair/Chair-Elect: STEPHEN E. Atkins, Political Science Subject Specialist, University of Illinois, Urbana, IL 61801 (87); Marta Lange, Head of Reference, North Carolina State University, Raleigh, NC 27695-7111 (70).

Member-at-Large: Vivian L. Campbell, Assistant Law Librarian for Collection Development, Georgetown University Law Library, Washington, DC 20001 (89); Barbara A. Burg, Reference Librarian, Widener Library, Harvard University, Cambridge, MA 02138 (69).

\section{Rare Books and Manuscripts Section}

Vice-Chair/Chair-Elect: Peter M. VAN Wingen, Head, Reference and Reader Services Section, Rare Book and Special Collections, Library of Congress, Washington, DC 20540 (292); Sally Sparks Leach, Assistant to the Director, Harry Ransom Humanities Research Center, University of Texas, Austin, TX 78713 (173).

Member-at-Large (three-year term): RosEMARY L. Cullen, Curator of the Harris Collection, Brown University, Providence, RI 01912 (309); Joe A. Springer, Curator, Mennonite Historical Library, Goshen College, Goshen, IN 46526 (135). 


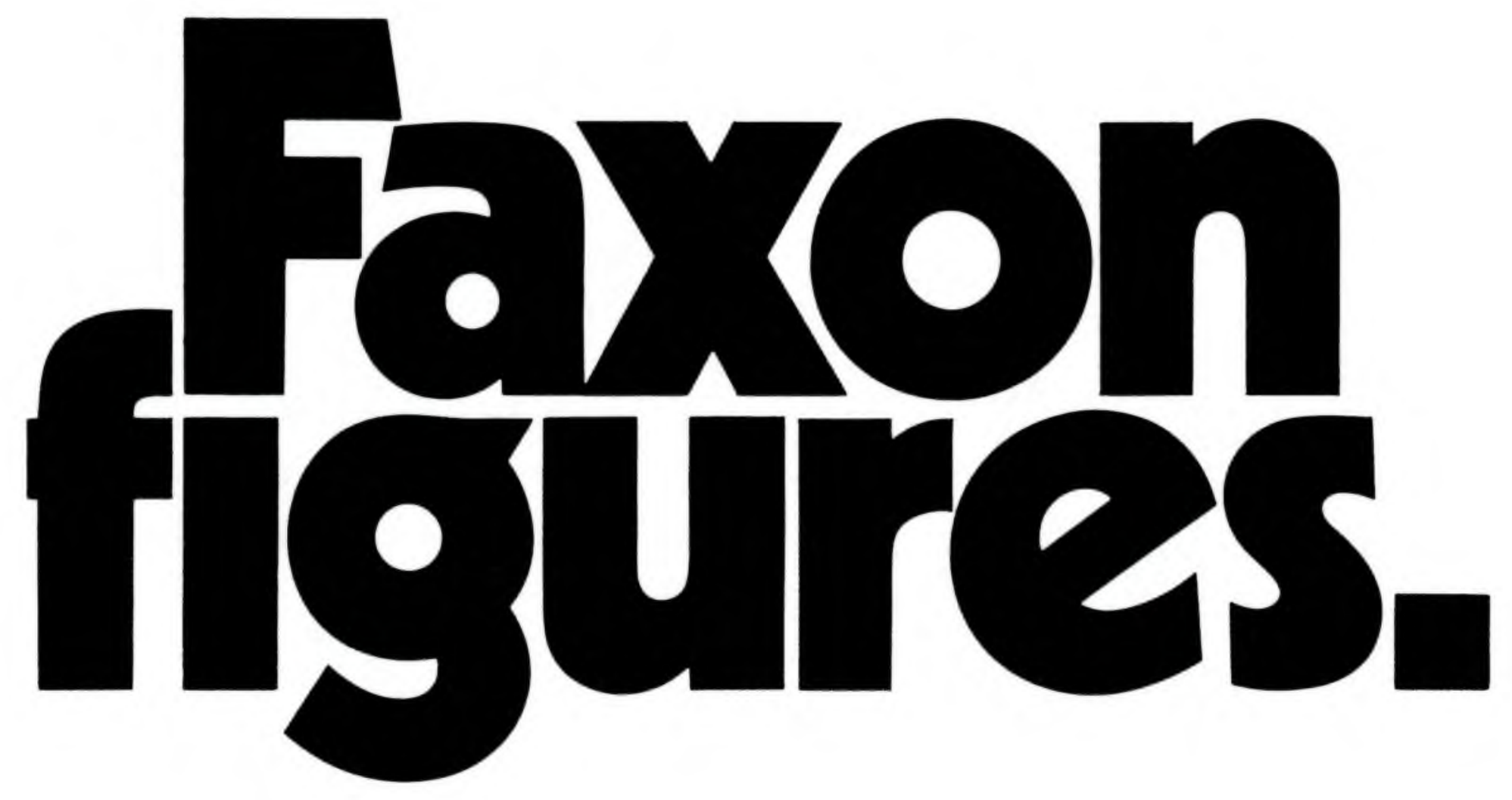

Productivity is a critical concern in today's library. That's why more and more decision makers are looking into Faxon. We can be the best source for all of your journal and continuation subscriptions. Our services enable you to devote your valuable personnel resources to other crucial library functions.

As a full service agent with access to more than 200,000 different periodicals, we can handle ordering, claiming, check-in, and routing. Our growing international network links you to other libraries, publishers, online systems, and networks.

If you can profit from improved productivity, a call to Faxon figures.

$1-800-225-6055$

or 1-617-329-3350 (collect)

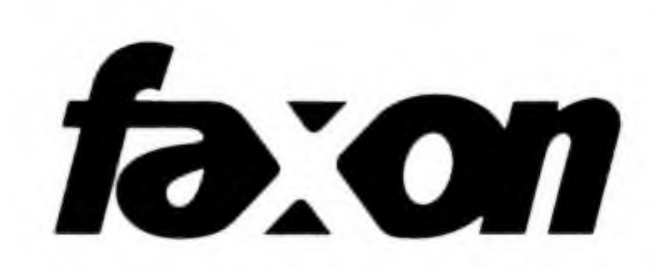




\section{Science and Technology Section}

Vice-Chair/Chair-Elect: Martin Kesselman, Information Services Librarian, Library of Science and Medicine, Rutgers University, Piscataway, NJ 08855 (224); Lois M. Pausch, Assistant Mathematics Librarian, University of Illinois, Urbana, IL 61801 (199).

Secretary: Beverlee French, Head, Science and Engineering Library, University of California, San Diego, La Jolla, CA 92093 (243); Donald G. Frank, Head, Science-Engineering Library, University of Arizona, Tucson, AZ 85721 (172).

\section{Slavic and East European Section}

Vice-Chair/Chair-Elect: StePhen D. CoRrSin, Deputy Associate Librarian for Technical Services, Brooklyn College, Brooklyn, NY 11210 (31); Viveca Seymour, Serials Cataloger, Stanford University, Stanford, CA 94305 (29).

Member-at-Large: MARIE BEDNAR, Head of Bibliographic Support Services, Pennsylvania State University, University Park, PA 18602 (20); Richard L. Kort, Slavic Cataloger, Boston Public Library, Boston, MA 02117 (11); Natalia B. Bezugloff, Foreign Literature Department Head, Cleveland Public Library, Cleveland, OH 441141271 (15); David J. Norden, Library Director, Hampden-Sydney College, Hampden-Sydney, VA 23943 (13); Cecelia L. Shores, Head, Acquisitions Department, Center for Research Libraries, Chicago, IL 60637 (3).

\section{University Libraries Section}

Vice-Chair/Chair-Elect: MaXIne H. Reneker, Associate University Librarian for Public Services, Arizona State University, Tempe, AZ 85287 (859); Jordan M. Scepanski, Director, University Library and Learning Resources, California State University, Long Beach, CA 90840 (794).
Secretary: Paula D. Watson, Assistant Director of General Services, University of Illinois, Urbana, IL 61801 (848); Nancy L. Baker, Associate Director for Public Services, University of Washington, Seattle, WA 98195 (753).

\section{Western European Specialists Section}

Vice-Chair/Chair-Elect: MARTHA L. Brogan, Assistant to the Vice President for Academic Affairs, University of Minnesota, Minneapolis, MN 55455 (114); David J. Cooper, Humanities Bibliographer, Johns Hopkins University, Baltimore, MD $21218(68)$.

Secretary: Ceres B. Birkhead, Assistant Head, Serials Department, University of Utah, Salt Lake City, UT 84112 (110); Leona L. Wise, German Bibliographer, University of Southern California, Los Angeles, CA 90089-0182 (62).

Member-at-Large: Susanne F. Roberts, Humanities Bibliographer, Yale University, New Haven, CT 06520 (110); Robert G. Sewell, Coordinator of Collection Management and Development, State University of New York, Stony Brook, NY 11794-3300 (70).

\section{Women's Studies Section}

Vice-Chair/Chair-Elect: Sarah M. Pritchard, General Reading Rooms Division, Library of Congress, Washington, DC 20540 (150); write-in (4).

Recorder: DEB BIGGS, Reference/Instruction Librarian, Undergraduate Library, University of Michigan, Ann Arbor, MI 48109-1185 (105); Judith Hudson, Head, Cataloging Department, State University of New York, Albany, NY 12222 (52).

Member-at-Large: Molly MAHONY, Reference Librarian, Keene State College, Keene, NH 03431 (113); Suzy Margot Slavin, Head, Reference Department, McGill University, Montreal, Quebec, Canada H3A IYl (39).

\title{
The International Association for Social Science Informa- tion Service and Technology (IASSIST)
}

\author{
By Diane Geraci \\ Social Science Bibliographer \\ State University of New York at Binghamton
}

The International Association for Social Science Information Service and Technology (IASSIST) is an organization which brings together administrators, computer programmers, data archivists, librarians, and researchers interested in quantitative analysis. IASSIST members facilitate access to so- cial science machine-readable data files (MRDFs) as well as promote commitment to the preservation and administration of these resources.

IASSIST was formed in 1974 following the cessation of National Science Foundation funding for the Council of Social Science Data Archives and 